\title{
Secondary School Teachers' Accessibility to Internet Facilities for Advanced Instruction in Nigeria
}

\author{
Adenike Aderogba Onojah ${ }^{1}$, Amos Ochayi Onojah ${ }^{2}$, Charles Olubode Olumorin ${ }^{3}$, Esther \\ O. Omosewo ${ }^{4}$ \\ ${ }^{1-4}$ Department of Educational Technology, University of Ilorin, Nigeria
}

DOI: $10.23917 /$ ijolae.v3i2.10686

Received: April 12 ${ }^{\text {nd }}, 2020$. Revised: December 21 $1^{\text {st }}, 2020$. Accepted: December $24^{\text {th }}, 2020$. Available Online: January $11^{\text {st }}, 2021$. Published Regularly: May $1^{\text {st }}, 2021$.

\begin{abstract}
For internet facilities to be adopted and integrated in schools, the resources should not only be available, it must also be accessible. The objectives of this study were to: identify internet facilities available for secondary school teachers; determine whether secondary school teachers are able to access the internet facilities; and investigate how teachers' gender influence the accessibility of internet facilities in secondary schools in Ilorin. The population of the study was limited to secondary school teachers in Ilorin, Nigeria and 251 respondents were randomly selected. There was no significant difference between male and female secondary school teachers' level of accessibility of internet facilities for instruction. The study concluded that teachers have access to the available internet facilities for advanced instruction. It was recommended that, Internet Service Providers (ISPs) should be allowed to establish centres on campus in order to bring online services close to teachers.
\end{abstract}

Keywords: advanced instruction, assessment, gender, internet facilities

\section{Corresponding Author:}

Amos Ochayi Onojah, Department of Educational Technology, University of Ilorin, Nigeria

Email: haymoresonojah@yahoo.com

\section{Introduction}

The guiding principle of education in $\mathrm{Ni}$ geria is equipping every citizen with knowledge, skills, attitudes and values as to derive maximum benefits from individuals' membership in society, lead a fulfilling life and contribute to the development and welfare of the community. Education is a social medium and process of acquisition of relevant knowledge, skills and attitudes for survival in a changing world (Sanni, Amosa \& Danmaigoro, 2017). The innovation that is taking place in ICT has positive effects on the way undergraduate students perform their functions of learning and instructional strategy, especially on the creation, dissemination and application of knowledge as well as skills.
Education also empowers communities and citizens to fully participate in development and prosperity. Education in its broadest sense is generally acclaimed as a tool that has a germane impact on the mind, character, or physical ability of an individual (Briggs, Ololube, Kpolovie, Amaele \& Amanchukwu, 2012). Owolabi, Oyewole, and Oke (2013), asserted that teachers are crucial within the teaching learning process. Hence, teachers constitute a major input in the accomplishment of educational goals and objectives in all nations.

ICT has been viewed as electronic-based technologies that are generally used to retrieve store, process and package information as well as provide access to knowledge (Abdulrahman, 2016). ICT encourages coope- 
rative learning, enhances teaching and learning process, and encourages communication through Websites, blogs and social networks (Augustine, et al. 2018). Similarly, Olanikawu, Omiola, and Aboyeji (2017) submitted that ICT is the sole creation of humankind that has thrown off and balance the conventional perceptions of time and information.

The effects of Information Communication and Technology on education cannot be over emphasized. Adebo, Adekunmi, and Daramola (2013) stated that the effects of ICT to classroom and education process include offering the opportunity for more student centered teaching; giving greater opportunity for communication and collaboration between teacher-to-teacher and student-to-student; exposing students greatly to vocational and workforce skills; providing opportunities for multiple technologies delivered by teachers; creating greater enthusiasm for learning amongst students, providing teachers with new sources of information and knowledge; preparing learners for the real world; and providing distance learners country-wide with online educational materials. According to Wadi and Sonia (2002), ICTs can enhance the quality of education by increasing learner's motivation and engagement; facilitating the acquisition of essential skills; and enhancing teacher training. Despite the relevance of computer and internet in the world educational systems, its application and use in a developing economy has not gained significant attention as expected, in particular among the student teachers, who are expected to impact such knowledge to the next generation, through primary and secondary education (Juliani et al, 2020).

Amoo, Ayodele and Egbowon (2000) defined teaching as "guiding the students to acquire basic knowledge, attitude and skills (through the use of various media and methods) that can be effectively applied to solve relevant problems and improve the environment. They added that, effective teaching requires a careful and selective application of learning theories, materials to meet the various conditions of a given learning situation. The Ashby commission was set up by the federal government in 1959 to make recommendation on the way and means of tackling the educational problem in Nigeria, one of the recommendations of the commission is that both the pre-service and in-service training of teachers should be intensified. The internet has allowed students, and teachers to learn and connect with each other as well as provide an avenue for both students and teachers to relate. Kofi Anan (2005) viewed ICT as the key to unlock the doors of the educational systems. The computer and its related technologies according to Adeyemo (2010) have formed an integral part of everyday life that it must be an ingredient in educating for participation in present and future society. The computers are essential tools, required for student teachers, to fit into the global information and communication technological development of the 21 st century. In the developing countries, ICT can be used to compensate for the inadequate well trained teachers and unavailability of equipment in the educational sector.

Adebo, Adekunmi, and Daramola, (2013) affirmed that despite the high percentage of women involved in teaching, studies have shown that female teachers in schools have less access to the usage of internet. Women internet users in almost all developing countries including Nigeria are very few. In the developed World, evidence shows a higher proportion of internet usage among the people, irrespective of gender and ages (Alison, Anne, and Christoph, 2010). Bola and Ogunlade (2012) established that students did not have as much access to Internet service as the staff 
and proximity to cybercafé and valid information contained from the Internet were their major motivating factors for surfing the Internet. It also found that the respondents strongly agreed that the purposes for their surfing the Internet were to register courses, enroll for exams, gather information for literature review, send and receive mails, amongst others.

Dede, Salzman \& Loftin (2013) established that limited access to technology in secondary schools may contribute to a lack of technology usage in schools. Soetan, Ogunlade, Fakomogbon, and Bolaji (2014) recommended more provisions need to be made concerning the availability of ICT tools for teaching at the early childhood education level. Similarly, Shehu, Urhefe and Promise (2015) noted that Internet will level the educational activities due to its availability to everyone, everywhere and any time, irrespective of gender, race, income or other socio-demographic characteristics. Furthermore, Daniel and Oghal (2015) stated that, Internet is the network of interconnected networks and Websites containing files; every website is also identified using an address for easy location.

In similar finding, Osuafor and Ofor (2015) reported that there was no significant difference between male and female lecturers on utilization of e-learning facilities in teaching in colleges of education. Similarly, Makewa, Kuboja, Yango and Ngussa (2014) reported that there was no significant difference in application of ICTs and research between male and female lecturers of Arusha University Tanzania. Moreover, Ogunlade, et al. (2015) reported that there was no significant difference between male and female respondents in the use of internet facilities. Furthermore, Nwankwoala, (2015) reported that, gender of university lecturers did not predict their usage of ICTs and also revealed that
ICTs usage contribute to the national development.

Nigeria's education system contemporary still faces challenges on the quality of education provided for students. National Policy on Education (Federal Republic of Nigeria, 2013) identified obsolete facilities as one of the numerous indicators of the poor state of education in Nigeria. Most primary and secondary schools have inadequate support services that enhance teaching and learning. Also, federal government recognized low funding for capital investment projects such as classrooms, ICT facilities, laboratories and so on. Various challenges are facing adequate implementation of ICT policy, dysfunctional telephone lines, and low level of internet connectivity amongst others. Emmanuel (2013) established most schools in Kwara state does not have internet facilities. Ministry of education and other government agencies still rely heavily on paper-based system in their daily activities. Although previous studies have examined availability of internet facilities among teachers or students for teaching and learning in either secondary schools or universities but none of these studies known to the researchers focused on its accessibility in Ilorin, Nigeria. To fill these identified gaps, this study therefore assessed the accessibility of internet facilities for instruction among secondary school teachers in Ilorin, Nigeria.

The purpose of this study was to accessed the internet facilities available for secondary school teachers; whether secondary school teachers are able to access the internet facilities; and determined whether gender of teachers influence the accessibility of internet facilities in secondary schools in Ilorin.

In order to conduct the research, the following research questions were raised and answered: (1) Are there internet facilities in secondary schools in Ilorin; (2) Are secondary school teachers in Ilorin able to access 
internet facilities in their schools; and (3) Will teachers' gender influence the accessibility of internet facilities in secondary schools in Ilorin.

\section{Research Hypotheses}

This following hypothesis was raised and tested at 0.005 level of significance in this study.

Ho1: there is no significant difference in teacher's accessibility of internet facilities based on gender

\section{Method}

This chapter presents the method and procedures that was employed in the process of collecting necessary and useful data for this research. This study employed a descriptive survey method. It involved the use of questionnaire; the response to which produce the required information from the teachers. The questionnaire was used to collect necessary information on secondary school teachers' accessibility of internet facilities. The population for the study consisted of all secondary school teachers in Ilorin, Nigeria. The target population consisted of the entire secondary teachers in Ilorin by purposive sampling. Over two hundred and fifty secondary school teachers based on their availability were randomly selected. An adapted questionnaire from the study of Ogunleye (2012) was used to elicit information from the respondents. It consisted of two sections. Section A required bio data of the respondents' personal information to know if their genders can have influence on their accessibility of internet facilities, Section B consisting ten items was on availability, accessibility of internet facilities among secondary school teachers which answer the research questions 1-5. Likert response mode of Strongly Agreed (SA), Agreed (A), Disagreed (D), and Strongly Disagreed (SD) was used.
The instrument was validated for the face validity and content validity by the researcher's supervisor and three other lecturers in the department of Educational Technology in University of Ilorin. The various suggestions after the validation were used to modify the instrument. In order to ascertain the consistency of the instrument, the instrument was pilot tested on twenty-five teachers in Ogbomoso, Oyo State which do not consist part of the study sample. Internal consistency of the instrument at 0.81 was tested using Cronbach alpha. After, obtaining letter of introduction to the appropriate departments, the school principals' permission was sought before the instruments are being administered with the help of a research assistant from each of the schools of the study. Data was collected through the questionnaire that were distributed to the respondents' schools within Ilorin, Nigeria.

The questionnaire were collected immediately from the teachers after filling them. The respondents were not coerced in filling the questionnaire as they will be given the opportunity to fill it at their own convenient time. Also, all authors cited in this work were properly referenced. Data collected through the questionnaire was subjected to descriptive and inferential statistics. Descriptive statistics (percentage, count and mean) was used to answer research questions. While in inferential statistics of t-test was used for the hypotheses. All the hypotheses were tested at 0.05 level of significance.

\section{Result and Discussion}

This chapter presents the analysis and results obtained from the data based on research questions and research hypotheses stated in chapter one. The results are preceded by the demographic information of the respondents. 
Table 1 Percentage Distribution of Respondents by Gender

\begin{tabular}{ccc}
\hline Gender & Frequency & \% \\
\hline Male & 119 & 47.4 \\
Female & 132 & 52.6 \\
Total & 251 & 100 \\
\hline
\end{tabular}

The distribution of secondary school teachers involved in the access and utilization of internet facilities for instruction according to gender showed that there was a difference in the distribution along gender lines. The results in Table 1 shows that 119 (47.4\%) were males while $132(52.6 \%)$ were females in all the schools.
This part presents the result of the analyses on access and utilization of internet facilities for instruction among secondary school teachers in Ilorin metropolis.

Research Question 1: Are there internet facilities in secondary schools in Ilorin?

Table 2 Teachers' Response towards the Availability of Internet Facilities in Secondary Schools

\begin{tabular}{lcc}
\hline \multicolumn{1}{c}{$\begin{array}{c}\text { Availability of Internet Facilities } \\
\text { in Secondary Schools }\end{array}$} & Yes & No \\
\hline $\begin{array}{l}\text { There is an e-library in the school. } \\
\begin{array}{l}\text { Teachers are allowed to use the e-library at } \\
\text { any time. }\end{array}\end{array}$ & $79(31.5 \%)$ & $172(68.5 \%)$ \\
$\begin{array}{l}\text { The school provides other means for teachers } \\
\text { to access information online. }\end{array}$ & $148(59.0 \%)$ & $176(70.1 \%)$ \\
$\begin{array}{l}\text { The government supplies computers and its } \\
\text { accessories to the school for helping teachers } \\
\text { enhance their instruction skills. }\end{array}$ & $136(54.2 \%)$ & $103(41.0 \%)$ \\
There are sufficient internet centers in schools. & & $115(45.8 \%)$ \\
\hline
\end{tabular}

The responses on the availability of internet facilities in Secondary Schools were investigated and the result presented in Table 2. It indicated that $31.5 \%$ of the respondents agreed that there was an e-library in their school and just a few of the respondents agreed to the statement that teachers are allowed to use the e-library any time. However, the majority of the respondents agreed that the school provides other means for teachers to access information online. Also, the government supplies computers and its accessories to the school for helping teachers enhance their instruction skills. But there are not sufficient internet centers in Nigerian secondary schools. On the whole, the study established that schools make no provision for internet facilities, likewise, the government does not supply computers and its accessories to the school for helping teachers enhance their instruction skills and as a result of this, the respondents' response on the availability of elibrary and sufficient internet centers in the school was low, and thereby teachers are not allowed to use the e-library any time.

Research Question 2: Are secondary school teachers in Ilorin able to access internet facilities in their schools? 
Table 3 Teachers' Response on the Access of Internet Facilities by Secondary School Teachers in Ilorin

\begin{tabular}{lcc}
\hline \multicolumn{1}{c}{$\begin{array}{c}\text { Access to Internet Facilities } \\
\text { in Secondary Schools }\end{array}$} & Yes & No \\
\hline $\begin{array}{l}\text { Teachers have been allowed to teach } \\
\text { with the internet in their classroom } \\
\text { practice. }\end{array}$ & $103(41.2 \%)$ & $148(58.8 \%)$ \\
$\begin{array}{l}\text { Information is very difficult to source } \\
\text { from the internet so I don't like using }\end{array}$ & $84(33.5 \%)$ & $167(66.5 \%)$ \\
it. & & \\
$\begin{array}{l}\text { I use the internet to communicate so- } \\
\text { cially than for instruction. } \\
\text { There is little access to the internet in } \\
\text { school. }\end{array}$ & $221(88.0 \%)$ & $30(12.0 \%)$ \\
The cost of accessing the internet is \\
too expensive.
\end{tabular}

Table 3 presents the result of teachers' responses to their access to internet facilities by Secondary school teachers in Ilorin. The findings revealed that $41.2 \%$ of the respondents agreed to the statement that teachers have been allowed to teach with the internet in their classroom practice while $58.8 \%$ disagreed with the statement. Also, it was revealed via the study that the majority of the respondents don't have access to internet facilities thereby making the information very difficult to source from the internet. Furthermore, it was deduced from the study that most of the respondents $(221,88.0 \%)$ use the internet to communicate socially than for instruction.
Besides, there is little access to the internet in the school. Lastly, $220(87.7 \%)$ majority of the respondents agreed that the cost of accessing the internet is too expensive. The findings indicated that most teachers use the internet to communicate socially than for instruction, many teachers admitted that the cost of accessing the internet is too expensive and that there is little access to the internet in the school.

\section{Hypothesis One}

Ho1: there is no significant difference in teacher's accessibility of internet facilities based on gender.

Table 4 T-test of Male and Female Secondary School Teachers' Level of Accessibility of Internet Facilities for Instruction

\begin{tabular}{cccccccc}
\hline Gender & N & $\mathbf{X}$ & SD & df & T & $\begin{array}{c}\text { Sig. } \\
\text { (2 tailed) }\end{array}$ & Remarks \\
\hline Male & 119 & 13.99 & 2.64 & 249 & .998 & .319 & Not Sig. \\
Female & 132 & 13.68 & 2.27 & & & & \\
\hline
\end{tabular}

From Table 4, it can be deduced that there was no significant difference between male and female secondary school teachers' level of accessibility of internet facilities for instruction in Ilorin. This is reflected in the result: $\mathrm{t}(249)=.998, \mathrm{p}>.05$. That is, the result of $\mathrm{t}$-value of .998 resulting in .319 significance value was greater than 0.05 alpha value. Thus, the hypothesis is not rejected. This implies that there was no significant difference between male and female secondary school teachers' level of accessibility of internet facilities for instruction. The benefits of ICT being nature-protecting, non-polluting, 
less energy consumption and above all, more human-friendly, it is applications are becoming indispensable parts of contemporary culture, spreading across the globe through general and vocational education (Ogunlade, Olafare, \& Udom, 2013). Similarly, ICT functions as a change agent on learning process, it impacted on place 'when' and 'where' to learn, improve quality of education and enhanced educational management (Kaur, 2015).

The result obtained indicated that schools make no provision for internet facilities, likewise the government does not supply computers and its accessories to the school for helping teachers enhance their instruction skills and as a result of this, the respondents' response on the availability of e-library and sufficient internet centres in the school was low, and thereby teachers are not allowed to use the e-library any time. Bola and Ogunlade (2012) established that students did not have as much access to Internet service. Dede, Salzman \& Loftin (2013) established that limited access to technology in secondary schools may contribute to a lack of technology usage.

The influence of gender on teachers' accessibility of internet facilities for instruction examined. The results of the t-test established no significant difference was established between secondary school male and female teachers' use and accessibility of internet. In support of these findings, Shehu, Urhefe and Promise (2015) noted that Internet will level the educational activities due to its availability to everyone, everywhere and any time, irrespective of gender.

Habib, Enite, and Aworo, (2015) conducted an empirical study on the accessibility and utilization of internet service in Nigeria Libraries, the outcome of the study reveals that majority of the participants asserted that internet was very accessible to them while some indicated that internet was not accessible to them at all. It also found that the participants strongly agreed that the reasons for which staff used the internet in Nigeria libraries are for research purpose, for current awareness services/ update of knowledge and to develop personal competencies among other. Professor S. A. Onasanya of the department of educational technology, University of Ilorin, Nigeria, who delivered a paper entitled, 'Educating for the next generation,' stated that teaching in the 21 st century had undergone a typical shift and stated that education must prepare pupils especially in Ilorin for success in a fast-changing and inter-connected world (Nwogu, 2016).

Furthermore, Apuke and Iyendo (2017) stated that the internet is a technology that has reshaped tertiary educational practice in terms of improving academic learning. It also revealed that lack of search skills, information overload, power outage, irrelevant information, difficulties in the navigation of the website, inaccessibility of some sites and unavailability/inaccessibility of the internet services were some of the challenges faced by the staff in Nigeria libraries. Olokoba, Abdullahi, Omosidi (2014) established that the nonavailability of ICT facilities will continue to hinder teachers from using the resources.

The findings have strong implication on the teaching process in Nigeria. It is an indication that there would be great improvement in the teaching and instruction process generally at all secondary schools if teachers could have access to internet facilities and fully utilize those facilities. Therefore, if schools and government make provision for internet facilities in schools, it could be of great help for teachers to be more competent in their use of the internet irrespective of their gender.

\section{Conclusion}

The result indicated that internet facilities are not available in secondary schools. It 
was also revealed that since there is low availability of internet facilities in the schools, teachers' use of internet facilities is low because they are not available despite the fact that teachers have knowledge of computer. This implies that more attention should be given to what can be done to positively improve the availability level of internet facilities in schools and seminars or training that will make them access the facilities for instruction regardless of their gender.

Based on the findings and conclusions of this study, the following recommendations were hereby made; Government, NGOs, and schools should organize conferences, trainings, and workshops to educate teachers on the benefits of using internet facilities and ICT generally for instruction; School owned internet centres should be established for easy access to the internet by the students; and Internet Service Providers (ISPs) should be allowed to establish centres on campus in order to bring online services close to teachers and the cost of accessing the internet at this centre should be affordable.

\section{References}

Abdulrahman, A. B. (2016). Effective Utilization of ICT for Repositioning of Library and Information Science Education in Tertiary Institutions in Nigeria. European Journal of Basic and Applied Sciences, 3 (2), 19-26

Adebo, G. M., Adekunmi, A. O. \& Daramola C. F. (2013). Gender Assessment of Computer and Internet Usage among Student Teachers in Ekiti State Tertiary Institutions. Journal of Education and Practice. 4(1), 23-36.

Adeyemo, S. A (2011). The Effect of Teachers "Perception and Students" Perception of Physics Classroom Learning Environment on their Academic Achievement in Senior Secondary Schools Physics. International Journal of Educational Research and Technology, 2 (1),
74- 81.

Adeyemo, S. A. (2010). The impact of Information and Communication Technology (ICT) on Teaching and Learning of Physics. International Journal of Educational Research and Technology, 2(1). 48-59. Available

at http://www.soegra.com.

Amoo, A. T. (2019). Assessment of Secondary School Teachers' Utilization of Mobile Learning Devices for Instructional Purposes in Iwo Local Government Area, Osun State.

Apuke, O. D., \& Iyendo, T. O., (2017). "Two Sides of a Coin: Revisiting The Impact of Social Networking Sites on Students' Performance in Selected Higher Educational Settings in Nigeria". Sci. Int. 29(6), 1265-1275.

Aremu, A \& Fasan, O. (2011). Teachers Training Implication of Gender and Computer Self-Efficacy for Technology Integration in Nigeria Schools. The African Symposium; An Online Journal of The African Educational Research Network 11(1),178-185.

Augustine, N., Daud, S. M., \& Kamaruddin, N. S. (2018). Teachers Use of ICT in Teaching and Learning in Aba North District Secondary Schools. Journal of Humanities and Social Science, 23 (4), 30-40.

Bian, C. D., \& Rice, M. L. (2014). The Influence of Gender on Attitudes, Perceptions and Uses of Technology. Journal on Research in Technology in Education, 39(2),119-132.

Bola, O. O., Ogunlade, O. O. 2012. "Accessibility and Utilization of Internet Service by Graduate Students in University of Lagos, Nigeria". International Journal of Humanities and Social Science, 2(1), 254-258. Retrieved from http://www.ijhssnet.com/journals/Vol_2_No_17_September_2012/28.pdf.

Briggs, T., Ololube, N. P., Kpolovie, P. J., Amaele, S., \& Amanchukwu, R. N. (2012). Evaluating The Quality of Public Early Childhood Education and Vision 
20: 2020: The Role of Government. African Journal of Economic and Sustainable Development, 1(3), 243-264.

Daniel, A. \& Oghal P. J. (2015). Awareness, Use and Impediments of Search Engines by Undergraduate Students in Delta State University, Abraka-Nigeria, Journal of Emerging Trends in Computing and Information Sciences, 6(12), 685692

Dede, C., Salzman, M.C. \& Loftin, R.B. 2013. "Science Space: Virtual Realities for Learning Complex and Abstract Scientific Concepts". In Proceedings of IEEE Virtual Reality Annual International Symposium, 246-253. http://www.vetl.uh.edu/ScienceSpace/absvir.html

Emmanuel, U. (2013). ICT in Education: Catalyst for Economic Growth in Nigeria. International Journal of Education and Research (IJERN) 1 (10), 233-239..

Federal Republic of Nigeria (2013). National Policy on Education. 4 Year Strategic Plan for the Development of the Education Sector: 2011-2015. 51 \& 81.

Habib, S., Enite, A. U., Aworo, P. (2015). "Accessibility and Utilization of Internet Service in Nigeria Libraries: An Empirical Study". International Journal of Academic Research and Reflection, 3 (5), 78-89. Retrieved from https://www.idpublications.org/wp-content/uploads/2015/05/accessibility-and-utilization-of-internet-service-in-nigeria-libraries.pdf.

Herath, C. T. \& Hewagamage, C. (2015). Analysis of ICT Usage for The Teaching and Learning Process by The Academics. International Journal of Computer and Information Technology, 4(5), 803808

Juliani, A., Mustadi, A., \& Lisnawati, I. (2020). "Make A Match Model" for Improving the Understanding of Concepts and Student Learning Results. Indonesian Journal on Learning and Advanced Education (IJOLAE), 3(1), 48-56.

Kamara (2010). Availability and the use of
Computer and Internet by Secondary School Teacher. www.academicjournals.org/article/ar...

Kaur, N. (2015). Using ICT in empowering teachers for quality education. International Journal of Scientific Research Engineering and Technology, 2(3), 8-12.

Khalil, A. J. \& Alrub, F. K. A. (2013). A Comparison of Search Engine's Features and Mechanizms. For Advanced Database Systems, 1, 1-8

Lavanya, J. \& Santharooban, S. (2018). "Usage of Online Resources by The Undergraduates Attached To The Faculty of Agriculture, Eastern university, Sri Lanka“. Journal of the University Librarians Association of Sri Lanka, 21(2), 89-105.

Makewa, L. N., Kuboja, J. M., Yango, M. \& Ngussa, B. M. (2014). ICT Integration in Higher Education and Students' Behavioural Change: Observation at University of Arusha Tanzania. American Journal of Educational Research, 2(11), 3038

Nwankwoala, H. N. (2015). An Investigation of Lecturers' and Students' of Icts In Nigerian University Education As A Panacea for National Development. Research on Humanities and Social Science, 5 (20), 1-10

Ogunlade, O. O., Fagbola, O. F., Ogunlade, A. A. \& Amosa, A. A. (2015). Assessment of Utilization of Internet Facilities Among Pre-Service Teachers in University of Ilorin, Nigeria. Malaysian Online Journal of Educational Technology, $3(3), 1-10$

Olajede, J. C. (2016). Perceptions and Attitudinal Behaviour of Lecturers in The Use of Information and Communication Technology Tools in Teaching/ Learning in Michael Okpara University of Agriculture Umudike. Scientific Papers Series Management, Economic, Engineering, Agriculture and rural Development, 16 (1), 207-210

Olanikawu, A. S., Omiola, M. A., \& Aboyeji, B. O. (2017). Integration of information and communication technology (ICT) in 
the Open and Distance learning in the 21st Century Nigeria. Conference Proceedings Association for Innovative Technology in Education (AITIE 2017) (pp. 233-238). Ilorin: Association for Innovative Technology in Education.

Olokoba, A. A., Abdullahi, A. M., \& Omosidi, S. A. (2014). Impact of Information Communication Technology (ICT) on The Management and Performance of Secondary School Teachers in Kwara State, Nigeria. International Journal of Education Learning and Development 2 (3), 60-67.

Osuafor, A. M. \& Ofor, N. A. S. (2015). Influence of Gender and Subject Specialization on Science Educators' Use of ELearning Facilities for Teaching in Nigerian Colleges of Education, International Journal for Cross-Disciplinary Subjects in Education, 5(4), 2649-2655.

Owolabi, T. O, Oyewole, B. K., \& Oke, J. O. 2013. The Role of Information and Communication Technologies in Nigeria. American Journal of Humanities and Social Sciences 2(3), 34-38.

Sanni, T. A., Amosa, A. A., \& Danmaigoro, H. (2017). Technology Education Students' Use of Web-Based Instruction for Learning: A Case Study of University of Ilorin, Nigeria. Conference Proceedings Association for Innovative Technology in Education (AITIE 2017) (pp. 231328). Ilorin: Association for Innovative Technology in Education.

Shehu, H., Urhefe, E. A. \& Promise, A. (2015). Accessibility and Utilization of Internet Service in Nigeria Libraries: An Empirical Study. International Journal of Academic Research and Reflection, 3(5), 78-89.

Soetan, A. K., Ogunlade, O. O., Fakomogbon, M. A., \& Bolaji, H. O. (2014). Availability and Utilization of Information and Communication Technology (ICT) in Early Childhood Education in Ilorin, Nigeria. Journal of Science, Technology, Mathematics and Education (JOSTMED), 10(3), 186-192.
Wadi, D. \& Sonia, J. (2002). ICT for Education: Potential and Potency. In W. Haddad \& A. Drexler (Eds.), Technologies for Education: Potentials, Parameters, and Prospects (Washington DC).

Yusuf, M.O. (2005). Information and Communication Technologies and Education: Analyzing the Nigerian National Policy for Information Technology. 